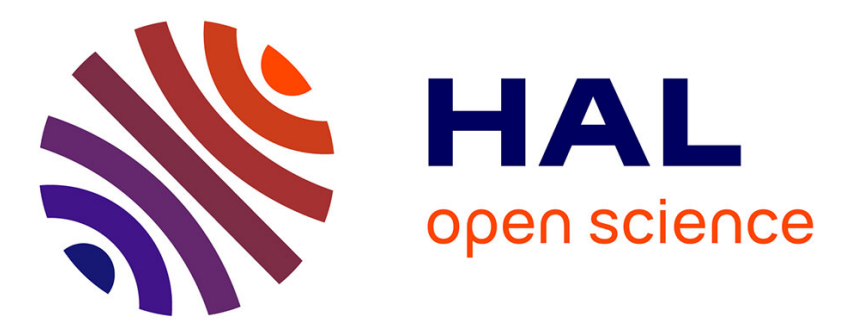

\title{
Genetics of wood quality attributes in Western Larch
}

Blaise Ratcliffe, Foster J. Hart, Jaroslav Klápště, Barry Jaquish, Shawn D. Mansfield, Yousry A. El-Kassaby

\section{To cite this version:}

Blaise Ratcliffe, Foster J. Hart, Jaroslav Klápště, Barry Jaquish, Shawn D. Mansfield, et al.. Genetics of wood quality attributes in Western Larch. Annals of Forest Science, 2014, 71 (3), pp.415-424. 10.1007/s13595-013-0349-x . hal-01101541

\section{HAL Id: hal-01101541 \\ https://hal.science/hal-01101541}

Submitted on 8 Jan 2015

HAL is a multi-disciplinary open access archive for the deposit and dissemination of scientific research documents, whether they are published or not. The documents may come from teaching and research institutions in France or abroad, or from public or private research centers.
L'archive ouverte pluridisciplinaire HAL, est destinée au dépôt et à la diffusion de documents scientifiques de niveau recherche, publiés ou non, émanant des établissements d'enseignement et de recherche français ou étrangers, des laboratoires publics ou privés. 


\title{
Genetics of wood quality attributes in Western Larch
}

\author{
Blaise Ratcliffe • Foster J. Hart • Jaroslav Klápště • \\ Barry Jaquish • Shawn D. Mansfield • \\ Yousry A. El-Kassaby
}

Received: 13 August 2013 / Accepted: 20 November 2013 / Published online: 11 December 2013

(C) INRA and Springer-Verlag France 2013

\begin{abstract}
- Context Wood quality traits are important to balance the negative decline of wood quality associated with selection for growth attributes in gymnosperm breeding programs. Obtaining wood quality estimates quickly is crucial for successful incorporation in breeding programs.

- Aims The aims of this paper are to: (1) Estimate genetic and phenotypic correlations between growth and wood quality attributes, (2) Estimate heritability of the studied traits, and (3) Assess the accuracy of in situ non-destructive tools as a representative of actual wood density.
\end{abstract}

Handling Editor: Jean-Michel Leban

Contribution of the co-authors BJ, SDM, YAE conceived designed the experiment; BJ, YAE supervised field data collection and SDM supervised X-ray densitometry data collection; BR, FJH conducted X-ray densitometry data collection; BR, JK, YAE conducted statistical analyses; BR wrote the original manuscript; JK, BJ, SDM, YAE reviewed and provided comments.

B. Ratcliffe • J. Klápště • Y. A. El-Kassaby $(\bowtie)$

Department of Forest and Conservation Sciences, Faculty of

Forestry, The University of British Columbia, Vancouver, BC V6T

1Z4, Canada

e-mail: y.el-kassaby@ubc.ca

F. J. Hart · S. D. Mansfield

Department of Wood Science, Faculty of Forestry, The University of British Columbia, Vancouver, BC V6T 1Z4, Canada

\section{B. Jaquish}

British Columbia Ministry of Forests, Lands and Natural Resource Operations, Tree Improvement Branch, Kalamalka Research Station and Seed Orchard, 3401 Reservoir Road, Vernon, BC V1B 2C7, Canada

\section{J. Klápště}

Department of Dendrology and Forest Tree Breeding, Faculty of Forestry and Wood Sciences, Czech University of Life Sciences Prague, Kamycka 129, Praha 6165 21, Czech Republic
- Methods Wood density (X-ray densitometry), tree height, diameter, volume, resistance drilling, acoustic velocity, and dynamic modulus of elasticity were estimated, along with their genetic parameters, for 1,200, 20-year-old trees from 25 open-pollinated families.

- Results Individual tree level heritabilities for non-destructive evaluation attributes were moderate $\left(\widehat{h}_{i}^{2}=0.37-0.42\right)$, wood density and growth traits were lower $\left(\widehat{h}_{i}^{2}=0.23-0.35\right)$. Favorable genetic and phenotypic correlations between growth traits, wood density, and non-destructive evaluation traits were observed. A perfect genetic correlation was found between resistance drilling and wood density $\left(r_{G}=1.00 \pm 0.07\right)$, while acoustic velocity and dynamic modulus of elasticity showed weaker genetic correlations with wood density $\left(r_{G}=0.25 \pm\right.$ $0.24 ; 0.46 \pm 0.21$, respectively).

- Conclusion This study confirmed that resistance drilling is a reliable predictor of wood density in western larch, while the weak genetic correlations displayed by acoustic velocity and dynamic modulus of elasticity suggest limited dependability for their use as fast in situ wood density assessment methods in this species.

Keywords Western larch - In situ wood quality assessment . Wood density $\cdot$ Modulus of elasticity $\cdot$ X-ray densitometry . Genetic correlation $\cdot$ Heritability

\section{Introduction}

Western larch (Larix occidentalis Nutt.) is a deciduous shade intolerant seral conifer native to the upper Columbia River Basin of southeastern British Columbia (B.C.) and northwestern USA (Schmidt and Shearer 1995). The species is valued for its fast growth, straight stem form, and higher density wood whose desirable attributes are often compared with that 
of Douglas-fir (Pseudotsuga menziesii (Mirb.) Franco.) (Schmidt et al. 1976; Wiemann 2010). It exhibits intrinsic tolerance to disease, insect damage and fire, while also possessing abundant genetic variation in growth traits (Mullins and McKnight 1981; Rehfeldt 1992; Carlson et al. 1995). Recently, western larch has gained increasing ecological and economic prominence considering the devastating impact of the mountain pine beetle (Dendroctonus ponderosae Hopk.) epidemic in lodgepole pine (Pinus contorta Dougl. Ex Loud. var. latifolia Engelm.) stands in the interior of B.C. (Burton 2010). The epidemic has resulted in large areas of forest with wide spread lodgepole pine death, of which many are predicted to be suitable for western larch (Rehfeldt and Jaquish 2010). Additionally, the epidemic has invoked debate regarding current forest policy to include greater species diversity, structure, and age class diversity to effectively increase forest health and resilience, which may also contribute to the prospect of western larch's future. The combination of desirable wood quality and growth traits and the opportunity for increased assisted migration (Leech et al. 2011) suggests western larch should be considered an important economic investment for the future.

British Columbia's western larch tree improvement program primarily focuses on improving volume attributes, while maintaining wood density (WD) and sufficient levels of adaptive and genetic variation (Jaquish et al. 1995; Woods 2011). The incorporation of wood quality attributes as a secondary selection trait is mainly aimed at balancing the negative decline of wood quality that is commonly associated with selection for increased growth rate in gymnosperm breeding programs (Cherry et al. 2008; El-Kassaby et al. 2011). Given the potential negative effects of this undesirable inverse relationship, it is important that tree breeders understand correlations between growth and important wood traits when focusing on improved tree growth and quality. Information regarding the genetic characteristics of wood quality and growth components specific to western larch, such as heritability, is relatively unexplored. However, the degree of genetic control of these traits in closely related trees within the Pinaceae family has been thoroughly investigated in the literature for hybrid larch (Larix $\times$ eurolepis Henry and Larix gmelinii var. japonica $\times$ L. kaempferi) (Jacques et al. 2004; Fujimoto et al. 2006), Douglas-fir (Chantre and Rozenberg 1997; Cherry et al. 2008; Ukrainetz et al. 2008; El-Kassaby et al. 2011) and loblolly pine (Pinus taeda L.) (Isik and Li 2003; Eckard et al. 2010).

Until recently, tree breeding has focused on traits such as growth, stem form, and disease resistance, while largely excluding quantitative wood quality attributes (Pellerin and Ross 2002). The principle measures of wood quality often include wood density as well as the wood flexural properties: modulus of rupture (MOR) and modulus of elasticity (MOE). These measures are not only costly and laborious, their destructive nature conflicts with the testing and selection populations' development. To avoid the loss of potentially valuable test trees and reduce costs of collecting wood trait information, in situ tools that provide rapid, indirect measurement of wood quality have been developed. Unfortunately, the lack of testing and concerns regarding the reliability, cost, and time efficiency have prevented these in situ tools from being widely implemented in genetic selection programs (Kellogg 1982; Pellerin and Ross 2002). Recently, however, methods relying on acoustic velocity and resistance drilling, have proven to be moderately effective for many commercial tree species (Isik and Li 2003; Jacques et al. 2004; Auty and Achim 2008; Bouffier et al. 2008; Cherry et al. 2008; Eckard et al. 2010; El-Kassaby et al. 2011). Additional species-specific information regarding the genetic control of the traits determined by non-destructive evaluation (NDE) tools is required to: (1) confirm their relationships to actual wood quality parameters, (2) gain knowledge of their correlations with growth traits, and (3) extend their utilization as reliable tools for use with other tree species.

One such NDE tool, the Resistograph ${ }^{\circledR}$ (Instrumenta Mechanic Labor, Inc., USA), provides an indirect estimate of wood density, a trait that typically has large genetic variance, high heritability, and strong effects on most end products of wood (Zobel and Jett 1995; Zobel and van Buijtenen 1989). Resistograph ${ }^{\circledR}$ technology was originally developed to detect internal defects in structural wood or hazard trees, but its use has been extended to genetic selection programs (Rinn et al. 1996; Pellerin and Ross 2002). The tool gives a measure of drilling resistance amplitude as the $3 \mathrm{~mm}$ tip of a precisely machined drill bit is passed through the radial profile of a tree with constant force and rotational speed. Newer models have the capability to provide a single density index value (Ukrainetz and O'Neill 2010). Variation in the profile measurement is caused by wood density differences, primarily annual early and late wood proportions. Further variation in the density profile can be introduced by wood defects, decay and resin pockets. Factors such as air temperature and moisture content of the wood have also been shown to have an effect on Resistograph ${ }^{\circledR}$ measurement (Rinn et al. 1996; Lin et al. 2003; Ukrainetz and O'Neill 2010).

In contrast, the Director ${ }^{\circledR}$ ST300 (Fibre-gen New Zealand), measures longitudinal acoustic velocity in standing trees that provides a surrogate measure of wood stiffness (MOE). A one-dimensional acoustic stress wave, produced by a hammer strike to a transmitting probe, travels through the sapwood portion of the tree and is measured by a receiving probe. The measurement is the stress wave's time of flight between the two probes which are set apart at a known distance. Variation in these acoustic measurements is caused primarily by differences in microfibril angle (MFA) (Gerhards 1982; Andrews 2002; Lindström et al. 2004; Lenz et al. 2013). MFA and wood density are both known to be integral components of 
MOE (Cave and Walker 1994; Evans et al. 2000), making the "ST300" a very useful tool to estimate wood stiffness. However, variation in acoustic velocity measurements can be caused by wood temperature and moisture content and can produce inaccurate estimates (Sandoz 1993; Gray et al. 2008; Gao et al. 2013). Acoustic technologies can also be coupled with X-ray density measurements to produce a dynamic estimate of MOE using the basic equation that describes one-dimensional wave theory: $\operatorname{MOE}_{\mathrm{D}}=\rho v^{2}$; where $\rho$ and $v$ represent density and velocity, respectively (Bucur 2006).

In this study, we randomly selected 1,200, 20-year-old western larch trees from 25 open-pollinated families grown on three progeny test sites near Cranbrook, B.C. We estimated wood density of increment cores using X-ray densitometry $\left(\mathrm{WD}_{\mathrm{X} \text {-ray }}\right)$, as well as standing wood density by drilling resistance amplitude (Resistograph $\left.{ }^{\circledR}\right)\left(\mathrm{WD}_{\text {Res }}\right)$. X-ray based estimates of wood density provide a highly accurate proxy for actual wood density (Zobel and Jett 1995). In addition, we determined acoustic velocity (Director ${ }^{\circledR}$ ST300) $\left(V_{\text {Dir }}\right)$ and calculated dynamic modulus of elasticity $\left(\mathrm{MOE}_{\mathrm{D}}\right)$ to determine the effectiveness of in situ wood quality estimates. The objectives of this study are to: (1) provide estimates of genetic and phenotypic correlations between growth and yield and wood quality attributes, (2) estimate the degree of genetic control (heritability) of the studied traits, and (3) assess the accuracy of in situ non-destructive tools as a representative of actual wood density.

\section{Material and methods}

\subsection{Genetic material and experimental design}

The genetic material originated from the B.C. Ministry of Forests, Lands and Natural Resource Operations' western larch Series 1 progeny tests for the East Kootenay Seed Planning Zone, which were established on four sites in 1987. Our study sampled trees from three of the four sites: Lamb Creek (Lat. $49^{\circ} 21^{\prime} \mathrm{N}$, Long. $115^{\circ} 21^{\prime} \mathrm{W}$, Elev. $1,000 \mathrm{~m}$ ), Sawmill Creek (Lat. $49^{\circ} 34^{\prime} \mathrm{N}$, Long. $116^{\circ} 02^{\prime}$ W, Elev. 1,700 m) and Semlin Creek (Lat. $49^{\circ} 22^{\prime} \mathrm{N}$, Long. $115^{\circ} 58^{\prime} \mathrm{W}$, Elev. 1,600 m). Sites were established with 1year-old container stock grown from open-pollinated seed collected from phenotypically selected parents from natural populations in southeastern B.C. Each site contained 208 families planted in a randomized complete-block design with four-tree-row plots and ten replicate blocks per site. Tree spacing was $2 \times 2\left(\mathrm{~m}^{2}\right)$ and the trial was surrounded by a single-tree buffer row. Twelve-hundred individual trees were sampled using a two-tree random selection method from 25 half-sib families across eight replicates on each of the three sites. Families were selected in such a way to provide a broader representation of tree growth across the entire trial (four sites) with five randomly selected families within five groups of growth pattern, based on performance across all sites.

\subsection{Growth and yield measurements}

Diameter at breast height (DBH - centimeters) and tree height (HT - meters) measurements were taken in 2010 for 20-yearold trees. Individual tree volume (VOL - cubic meters) was then determined using the following logarithmic equation for western larch tree volume derived by Millman (1976):

$\log \mathrm{Vol}=-4.350486+1.723600(\log \mathrm{DBH})+1.135270(\log \mathrm{HT})$

\subsection{In situ wood quality}

Indirect measurements of wood quality consisted of acoustic velocity ( $V_{\text {Dir }}$-meters per second) and drilling resistance amplitude $\left(\mathrm{WD}_{\mathrm{Res}}\right)$ measured on standing trees using the Director $^{\circledR}$ ST300 and IML Resistograph ${ }^{\circledR}$ F300, respectively. To minimize tree sampling variation due to diurnal tree moisture and temperature differences, the measurements were completed over a short period from May 25th 2010 to June 28th 2010, and only during similar weather conditions (i.e., warm and dry). Both the "F300" and "ST300" measurements are only significantly affected by moisture and temperature when the ambient temperature is below the freezing point of water (Ukrainetz and O'Neill 2010; Gao et al. 2013). Operating procedures for both instruments were performed in accordance to the respective manufacturer's Operating Manual and Instructions.

Director ${ }^{\circledR}$ ST300 acoustic velocity measurements were completed so that the distance between the two probes $(1 \mathrm{~m})$ was centered at approximately breast height $(1.3 \mathrm{~m})$ and so that the probes penetrated the subcortical tissue of each tree. To account for environmental (aspect) effects on wood growth, the means of three acoustic velocity measurements for two perpendicular directions was averaged to give a single velocity estimate for each tree.

Resistograph ${ }^{\circledR}$ F300 measurement consisted of two perpendicular bark-to-bark drilling measurements to account for environmental (aspect) effects on wood growth. Drilling was performed $1 \mathrm{~m}$ above the root collar. The density index value output was recorded for each aspect and the mean value of the two indices was used as a surrogate for wood density.

\subsection{Wood density}

Wood density ( $\mathrm{WD}_{\mathrm{X} \text {-ray }}$ - kilograms per cubic meter) for each tree was estimated by X-ray densitometry (QTRS-01X Tree 
Ring Analyzer; Quintek Measurement Systems Inc. Knoxville, TN) using $5 \mathrm{~mm}$ diameter bark-to-bark increment cores taken from each tree $1.3 \mathrm{~m}$ above the root collar. The increment cores were precision cut to a width of $1.68 \mathrm{~mm}$ with a dual-blade pneumatic saw to create a radial surface suitable for use with the X-ray densitometer. Cut samples were immersed in acetone for 5 days (which consisted of two exchanges of fresh acetone) to remove extractives and then airdried, and allowed to acclimate to $7 \%$ moisture prior to density determination. Annual ring boundaries on the density profiles were automatically defined by the QTRS-01X software (Quintek Measurement Systems Knoxville, TN) according to an earlywood and latewood threshold density value set by the user $\left(600 \mathrm{~kg} / \mathrm{m}^{3}\right)$. The scanned profiles were visually examined for defects such as cracks, knots, resin pockets, and accuracy of annual ring boundaries. Corrections were completed manually using the QTRS-01X software. $\mathrm{WD}_{\mathrm{X} \text {-ray }}$ of each core was calculated as the mean of the individual weighted ring densities by ring area. This method eliminated variation in annual ring numbers between core samples due to differences in core lengths from breakage as a result of wood defects (e.g., knots, cracks, resin pockets).

Dynamic modulus of elasticity $\left(\mathrm{MOE}_{\mathrm{D}}-\mathrm{MPa}\right)$ was estimated using Eq. 2 (Bucur 2006) for each tree using $V_{\text {Dir }}$ (velocity) and $\mathrm{WD}_{\mathrm{X} \text {-ray }}$ values:

$\mathrm{MOE}_{\mathrm{D}}=V_{\text {Dir }}^{2} \cdot \mathrm{WD}_{\mathrm{X} \text {-ray }}$

\subsection{Statistical methods}

Data were analyzed using $\mathrm{SAS}^{\circledR}$ software version 9.2 of the SAS System for Windows (SAS Institute Inc. USA). The UNIVARIATE procedure was used to verify the assumptions of regression analysis and check normality of trait data using the Shapiro-Wilk test $(p>0.05)$. Data transformations and deletion of outliers were used to meet assumptions when necessary.

Variance components were estimated using ASReml (VSN International Ltd. UK) (Gilmour et al. 2002) according to the following linear mixed model:

$$
Y_{j k l m}=\mu+S_{j}+F_{k}+B / S_{l(j)}+S F_{j k}+F B / S_{k l(j)}+E_{j k l m}
$$

where, $Y_{j k l m}$ is the response variable of the $m$ th tree in the $l$ th replicate of the $k$ th family in the $j$ th site, $\mu$ is the overall mean, $S_{j}$ is an estimate of the fixed effect for site $j\left(j=1\right.$ to 3 ), $F_{k}$ is an estimate of the random effect for family $k$ ( $k=1$ to 25$), B$ / $S_{l(j)}$ is an estimate of the random effect for replicate $l$ nested in site $j$ ( $(=1$ to 8$), S F_{j k}$ is an estimate of random site-family interaction, $F B / S_{k l(j)}$ is an estimate of random family-replicate interaction nested within site, and $E_{j k l m}$ is the random residual error effect of the $m$ th tree in the $l$ th replicate of the $k$ th family in the $j$ th site, respectively.

Considering open-pollinated families as half-sib families, an estimate of among family variance $\left(\sigma_{F}^{2}\right)$ is equal to $\frac{1}{4} \sigma_{A}^{2}$ (Falconer and Mackay 1996). Therefore, the additive genetic variance $\left(\sigma_{A}^{2}\right)$ equals $4 \sigma_{F}^{2}$. However, overestimation of this component can occur due to inbreeding (Namkoong 1966). As a result of the inbreeding character of western larch established by El-Kassaby and Jaquish (1996), the coefficient of relationship was adjusted to $\frac{1}{3}$ and the additive genetic variance component was conservatively estimated as $3 \sigma_{F}^{2}$ after similar studies in tamarack (Larix laricina (Du Roi) K. Koch) (Park and Fowler 1987; Farmer et al. 1993; Perron et al. 2013). Further, Falconer and Mackay (1996) state that total population variance is equal to phenotypic variance, which is the sum of all separate random variance components. Therefore, narrow-sense (individual tree) heritabilities $\left(\widehat{h}_{i}^{2}\right)$ were estimated by dividing $\sigma_{A}^{2}$ by the total phenotypic variance (White et al. 2007) (Eq. 4):

$\widehat{h}_{i}^{2}=\frac{3 \widehat{\sigma}_{F}^{2}}{\widehat{\sigma}_{F}^{2}+\widehat{\sigma}_{S F}^{2}+\widehat{\sigma}_{F B / s}^{2}+\widehat{\sigma}_{E}^{2}}$

where, $\sigma_{F}^{2}, \sigma_{S F}^{2}, \sigma_{F B / S}^{2}$, and $\sigma_{E}^{2}$ are the family, site-family interaction, family-replicate within site and residual error variance components respectively.

The likelihood ratio test (Eq. 5) was used to examine the significance of factors included in the linear model:

$\lambda_{L R}=-2 \times\left(\log L_{R}-\log L_{F}\right)$

where, $\log L_{R}$ and $\log L_{F}$ are the $\log$ likelihood values of the reduced model and the full model respectively.

Phenotypic and genetic correlations (Eq. 6) were estimated as Pearson's product-moment correlation coefficients as follows:

$r_{P_{x y}}=\frac{\operatorname{Cov}_{p_{(x, y)}}}{\sqrt{\sigma_{p_{x}}^{2} \cdot \sigma_{p_{y}}^{2}}}$ and $r_{G_{x y}}=\frac{\operatorname{Cov}_{g_{(x, y)}}}{\sqrt{\sigma_{g_{x}}^{2} \cdot \sigma_{g_{y}}^{2}}}$

where, $x, y$ are two traits of interest; $\sigma_{p_{x}}^{2}, \sigma_{p_{y}}^{2}$ or $\sigma_{g_{x}}^{2}, \sigma_{g_{y}}^{2}$ is the phenotypic or genetic variance (family component) of trait $x$ or $y$; and $\operatorname{Cov}_{p_{(x, y)}}$ or $\operatorname{Cov}_{g_{(x, y)}}$ is the phenotypic or genetic covariance. Phenotypic correlations were tested for significance using standard correlation tables and genetic correlations were tested based on their standard errors.

The Delta Method (Lynch and Walsh 1998) was used to estimate the standard errors for variance components, genetic 
correlations and individual tree heritabilities using ASReml (Gilmour et al. 2002).

Community identification tools were used to visualize the phenotypic and genetic correlations as social networks using Gephi (Bastian et al. 2009). Specifically, the Louvian modularity algorithm (Blondel et al. 2008) was used to identify the number of communities and the Force Atlas approach was used for the network layout.

\section{Results}

Descriptive statistics for the studied phenotypic traits are shown in Table 1 . Of all wood quality traits, $\mathrm{WD}_{\mathrm{X} \text {-ray }}$ showed the least variation among individuals $(\mathrm{CV}=8.37 \%$; range, $\left.475.82-872.46 \mathrm{~kg} / \mathrm{m}^{3}\right)$, while $\mathrm{MOE}_{\mathrm{D}}$ showed the greatest variation $(\mathrm{CV}=22.10 \%$; range, 3,478.56-15,618.18 $\mathrm{MPa})$. Among growth traits, VOL was highly variable and displayed the greatest variation $\left(\mathrm{CV}=70.86 \%\right.$; range, $\left.0.01-0.09 \mathrm{~m}^{3}\right)$, while HT showed the least ( $\mathrm{CV}=23.71$; range, $2-13 \mathrm{~m})$. The Lamb Creek site consistently displayed the largest mean HT, $\mathrm{DBH}$, and VOL values of all test sites (data not shown).

Variance components and individual tree narrow-sense heritability estimates are displayed in Table 2 . The family effect for all indirect measures of wood quality (i.e., $\mathrm{WD}_{\text {Res, }}$, $\mathrm{MOE}_{\mathrm{D}}$, and $V_{\text {Dir }}\left(\right.$ range, $\left.11.45\left(\mathrm{MOE}_{\mathrm{D}}\right)-13.35 \%\left(V_{\text {Dir }}\right)\right)$ accounted for a greater proportion of the total variance than the direct measure $\left(\mathrm{WD}_{\mathrm{X} \text {-ray }}(6.72 \%)\right)$. The family effect for all growth traits was also significant (range, 7.40 (DBH)$10.56 \%(\mathrm{HT}))$. Site $\times$ family interaction $(G \times E)$ was not significant for all traits except DBH $(p<0.05)$. Replicate nested in site variance components were significant for all traits, however, their contribution to the total variance was minimal for growth (range, 5.56 (DBH) $-9.21 \%(\mathrm{HT})$ ), and minimal to moderate for wood quality traits (range, $4.52\left(V_{\text {Dir }}\right)-16.11 \%$ $\left.\left(\mathrm{WD}_{\mathrm{X} \text {-ray }}\right)\right)$. The family $\times$ replicate/site component was significant for all traits except $\mathrm{WD}_{\mathrm{X} \text {-ray }}$ (range, $6.70\left(\mathrm{WD}_{\mathrm{X} \text {-ray }}\right)^{-}$ $32.66 \%(\mathrm{HT}))$. Residual variation produced the greatest proportion of total variation for all traits, with percent contribution ranging from $47.57(\mathrm{HT})-70.47 \%\left(\mathrm{WD}_{\mathrm{X} \text {-ray }}\right)$.

Individual tree narrow-sense heritability estimates were moderate for all wood quality traits and all estimates had reasonably small standard errors (Table 2). The heritability estimates of the two NDE attributes $\left(\widehat{h}_{i}^{2}=0.42\left(\mathrm{WD}_{\text {Res }}\right) ; 0.42\left(V_{\text {Dir }}\right)\right)$ were greater than $\mathrm{WD}_{\mathrm{X} \text {-ray }}\left(\widehat{h}_{i}^{2}=0.24\right)$. Growth trait heritability estimates $\left(\widehat{h}_{i}^{2}=0.35(\mathrm{HT}) ; 0.23(\mathrm{DBH}) ; 0.26(\mathrm{VOL})\right)$ were lower and generally similar to that of $\mathrm{WD}_{\mathrm{X} \text {-ray. }}$

The 42 combined phenotypic and genetic correlation estimates for growth (DBH, HT, VOL) and wood quality traits $\left(\mathrm{WD}_{\text {Res }}, \mathrm{WD}_{\mathrm{X} \text {-ray }}, V_{\text {Dir, }}, \mathrm{MOE}_{\mathrm{D}}\right)$ are given in Table $3 . \mathrm{DBH}$ and HT were strongly and highly significantly correlated $(p<$ $0.01)\left(r_{P}=0.89 ; r_{G}=0.95\right)$. Similarly, strong phenotypic correlations were observed between HT-VOL $\left(r_{P}=0.94\right)$ and DBH-VOL $\left(r_{P}=0.99\right)$ as well as their genetic correlations $\left(r_{G}=0.98 ; r_{G}=0.99\right.$, respectively).

The correlation between $\mathrm{WD}_{\mathrm{Res}}$ and $\mathrm{WD}_{\mathrm{X} \text {-ray }}$ at both the phenotypic and genetic levels was highly significant $(p<0.01)$ $\left(r_{P}=0.44 ; r_{G}=1.00\right)$. Correlation between $\mathrm{WD}_{\text {Res }}$ and $V_{\text {Dir }}$ produced weak and non-significant $(p>0.05)$ results in this study. Comparatively, the phenotypic correlation between $V_{\text {Dir }}$ and $\mathrm{WD}_{\mathrm{X} \text {-ray }}$ was non-significant $(p>0.05)$, while the genetic correlation between the two traits was weak $\left(r_{G}=\right.$ $0.25)$. $\mathrm{MOE}_{\mathrm{D}}$ produced similar genetic and phenotypic correlations as $V_{\text {Dir }}$ did with $\mathrm{WD}_{\text {Res }}$. $V_{\text {Dir }}$ and $\mathrm{MOE}_{\mathrm{D}}$ were strongly correlated $\left(r_{P}=0.92 ; r_{G}=0.97\right)$.

In this study, the genetic and phenotypic correlations between HT and all measures of wood quality were weak to moderate, while DBH produced few significant correlations with the studied wood traits. $\mathrm{WD}_{\text {Res }}$ produced weak and positive phenotypic correlations with growth traits (range, 0.20 (DBH-WD $\mathrm{Res}_{\text {Res }}$ ) to 0.28 (HT-WD $\left.\mathrm{Wes}_{\text {Res }}\right)$, and was only significantly genetically correlated with $\mathrm{HT}\left(r_{G}=0.25\right)$. $\mathrm{WD}_{\mathrm{X} \text {-ray }}$ reflected the correlations between $\mathrm{WD}_{\mathrm{Res}}$ and growth traits; however, $\mathrm{WD}_{\mathrm{X} \text {-ray }}$ showed a moderate genetic correlation with HT and non-significant phenotypic correlation with DBH.

Table 1 Sample size $(n)$ and descriptive statistics for growth and wood quality traits of 20-year-old western larch progeny tests

\begin{tabular}{|c|c|c|c|c|c|c|c|}
\hline Trait & Units & $n$ & Mean & SD & CV (\%) & Min & Max \\
\hline DBH & $\mathrm{cm}$ & 1,115 & 8.50 & 2.58 & 30.35 & 1.40 & 15.70 \\
\hline HT & $\mathrm{m}$ & 1,115 & 8.23 & 1.951 & 23.71 & 2.00 & 13.00 \\
\hline VOL & $\mathrm{m}^{3}$ & 1,115 & 0.03 & 0.02 & 70.86 & 0.01 & 0.09 \\
\hline $\mathrm{WD}_{\text {Res }}$ & - & 1,120 & 26.80 & 3.85 & 14.37 & 16.70 & 44.55 \\
\hline$V_{\text {Dir }}$ & $\mathrm{m} / \mathrm{s}$ & 1,038 & 3.65 & 0.39 & 10.66 & 2.26 & 4.67 \\
\hline $\mathrm{WD}_{\mathrm{X} \text {-ray }}$ & $\mathrm{kg} / \mathrm{m}^{3}$ & 989 & 661.30 & 55.32 & 8.37 & 475.82 & 872.46 \\
\hline $\mathrm{MOE}_{\mathrm{D}}$ & $\mathrm{MPa}$ & 931 & $8,887.76$ & $1,964.28$ & 22.10 & $3,478.56$ & $15,618.10$ \\
\hline
\end{tabular}

$n$ number of observations, $S D$ standard deviation, $C V$ coefficient of variation, $H T$ tree height, $V O L$ estimated volume, $D B H$ diameter at breast height, $V_{D i r}$ acoustic velocity, $W D_{\text {Res }}$ resistograph wood density, $W D_{X-\text { ray }}$ X-ray wood density, $M O E_{D}$ dynamic modulus of elasticity 
Community identification of the results in Table 3 produced three distinct logical trait clusters as identified in the social network analysis (Figs. 1 and 2): cluster I (green), growth attributes (HT, DBH, VOL); cluster II (blue), acoustic attributes $\left(V_{\mathrm{Dir}}, \mathrm{MOE}_{\mathrm{D}}\right)$; and cluster III (red), density attributes $\left(\mathrm{WD}_{\mathrm{Res}}, \mathrm{WD}_{\mathrm{X} \text {-ray }}\right)$. Traits within each cluster were always strongly and positively correlated (shown by thick lines), and while the relationships between clusters were usually positive, some were negatively correlated (e.g., $\mathrm{WD}_{\mathrm{Res}}{ }^{-}$ $\left.V_{\text {Dir, }}, \mathrm{WD}_{\mathrm{X} \text {-ray }}-V_{\text {Dir, }}, \mathrm{DBH}-V_{\text {Dir }}\right)$.

\section{Discussion}

\subsection{Descriptive statistics}

Descriptive statistics in Table 1 were consistent with those reported by Fujimoto et al. (2006), who found a similar trend for hybrid larch (L. gmelinii var. japonica $\times$ L. kaempferi). The mean $W_{\text {X-ray }}\left(661.30 \mathrm{~kg} / \mathrm{m}^{3}\right)$ was greater than other reported dry wood densities of western larch $\left(600 \mathrm{~kg} / \mathrm{m}^{3}\right.$ : Summitt and Sliker 1980; $640 \mathrm{~kg} / \mathrm{m}^{3}$ : Mullins and McKnight 1981; $450 \mathrm{~kg} / \mathrm{m}^{3}$ : Jozsa and Sen 1992; $520 \mathrm{~kg} /$ $\mathrm{m}^{3}$ : Miles and Smith 2009; $550 \mathrm{~kg} / \mathrm{m}^{3}$ : Wiemann 2010). Comparatively, western larch wood density is the highest among commercially important tree species in B.C. (Jozsa and Sen 1992). This attribute makes western larch wood desirable for a wide range of structural applications where strength is required (Mullins and McKnight 1981). Further, western larch wood can be used as a reliable substitute for the economically important Douglas-fir wood.

\subsection{Variance components}

The significant family effect for all growth traits agrees with previously reported results for juvenile height growth in western larch (Rehfeldt 1992). The low variance contribution of the site $\times$ family interaction $(G \times \mathrm{E})$ component suggests that the measured traits were relatively uniform within each family and there was good correlation of genetic performances across the three test sites. The large contribution of residual variation was expected and concurs with other published results from conifer progeny tests (Stonecypher et al. 1996; review by Ukrainetz et al. 2008).

\subsection{Heritability}

Heritability estimates of the two NDE attributes $\left(\widehat{h}_{i}^{2}=0.42\right.$ $\left.\left(\mathrm{WD}_{\text {Res }}\right) ; 0.42\left(V_{\text {Dir }}\right)\right)$ were much greater than the 0.24 of $\mathrm{WD}_{\mathrm{X} \text {-ray }}$, suggesting moderate genetic control over these traits. Given the moderate heritability of the NDE traits there is potential for their use in western larch breeding programs to 
Table 3 Estimates of phenotypic (above the diagonal) and genetic ( \pm standard error) (below the diagonal) correlations at the family level for all growth, yield and wood quality traits

\begin{tabular}{|c|c|c|c|c|c|c|c|}
\hline & $\mathrm{DBH}$ & HT & VOL & $W_{\text {Res }}$ & $V_{\text {Dir }}$ & $\mathrm{WD}_{\mathrm{X} \text {-ray }}$ & $\mathrm{MOE}_{\mathrm{D}}$ \\
\hline DBH & & $0.89 * *$ & $0.99 * *$ & $0.20 * *$ & $-0.002^{\mathrm{ns}}$ & $0.04^{\mathrm{ns}}$ & $0.02^{\mathrm{ns}}$ \\
\hline HT & $0.95 \pm 0.03$ & & $0.94 * *$ & $0.28 * *$ & $0.16 * *$ & $0.13 * *$ & $0.20 * *$ \\
\hline VOL & $0.99 \pm 0.01$ & $0.98 \pm 0.02$ & & $0.23 * *$ & $0.05^{\mathrm{ns}}$ & $0.07 *$ & $0.08 *$ \\
\hline$W_{\text {Res }}$ & $0.01 \pm 0.27$ & $0.25 \pm 0.23$ & $0.08 \pm 0.26$ & & $-0.05^{\mathrm{ns}}$ & $0.44 * *$ & $0.12 * *$ \\
\hline$V_{\text {Dir }}$ & $0.36 \pm 0.25$ & $0.45 \pm 0.20$ & $0.39 \pm 0.23$ & $0.01 \pm 0.24$ & & $-0.04^{\mathrm{ns}}$ & $0.92 * *$ \\
\hline $\mathrm{WD}_{\mathrm{X} \text {-ray }}$ & $0.15 \pm 0.28$ & $0.38 \pm 0.23$ & $0.22 \pm 0.26$ & $1.00 \pm 0.07$ & $0.25 \pm 0.24$ & & $0.34 * *$ \\
\hline $\mathrm{MOE}_{\mathrm{D}}$ & $0.36 \pm 0.25$ & $0.49 \pm 0.20$ & $0.40 \pm 0.23$ & $0.25 \pm 0.23$ & $0.97 \pm 0.02$ & $0.46 \pm 0.21$ & \\
\hline
\end{tabular}

$H T$ tree height, $V O L$ estimated volume, $D B H$ diameter at breast height, $V_{D i r}$ acoustic velocity, $W D_{\text {Res }}$ resistograph wood density, $W D_{X-r a y} \mathrm{X}$-ray wood density, $M O E_{D}$ dynamic modulus of elasticity, $n s$ non-significant

${ }^{* *} p \leq 0.0001, * 0.05 \leq p>0.0001$

produce a favorable response. Growth trait heritability values were lower than those of NDE traits suggesting greater environmental influence on the former. Overall, growth trait heritabilities are congruent with that of other conifer species (Cornelius 1994). The heritability estimate for HT in this study was considerably higher than that reported for 7-year height from populations in the Inland Empire (Fins and Rust 1989), with the disparity likely owing to factors such as tree age, genetic origin, and environmental differences between the two studies.

\subsection{Genetic and phenotypic correlations}

The strong genetic and phenotypic correlations between growth traits (DBH, HT, VOL) were expected and suggest a strong underlying genetic based relationship between these two growth traits in western larch (Table 3).

Estimates of wood quality typically correlated well with their respective underlying characteristics in this study. The

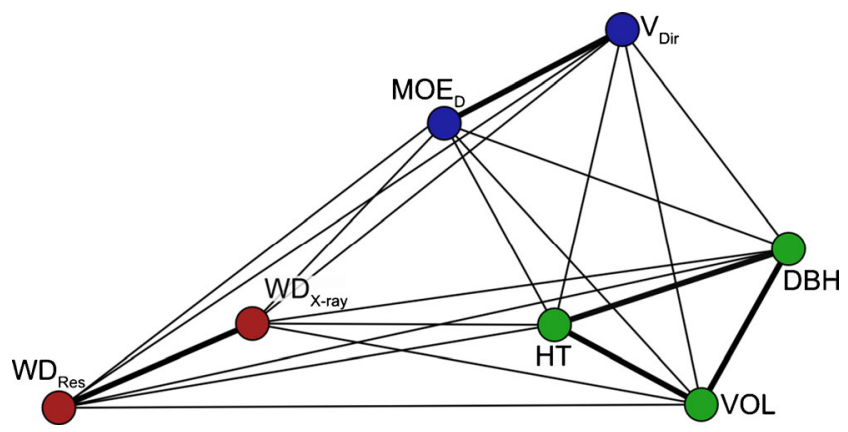

Fig. 1 Network analysis based on genetic correlations among measured traits (line thickness within trait clusters for emphasis). Cluster I [green] ( $H T$ tree height, $V O L$ estimated volume, $D B H$ diameter at breast height); cluster II [blue] ( $V_{\text {Dir }}$ acoustic velocity, $M O E_{D}$ dynamic modulus of elasticity); cluster III [red] $\left(W D_{\text {Res }}\right.$ resistograph wood density, $W D_{X \text {-ray }}$ X-ray wood density) perfect genetic correlation between $\mathrm{WD}_{\mathrm{Res}}$ and $\mathrm{WD}_{\mathrm{X} \text {-ray }}$ was consistent with previously published results for species within the Pinaceae family (Bouffier et al. 2008; Eckard et al. 2010; El-Kassaby et al. 2011). Over the past decade, genetic studies employing the Resistograph ${ }^{\circledR}$ have shown very strong and favorable genetic correlations $\left(r_{G}=0.74-0.95\right)$ with wood density measures for Caribbean pine (Pinus caribaea Morelet) and radiata pine (Pinus radiata D. Don) (Gantz 2002), loblolly pine (Isik and Li 2003; Eckard et al. 2010), maritime pine (Pinus pinaster Aiton) (Bouffier et al. 2008), shortleaf pine (Pinus echinata Mill.) (Gwaze and Stevenson 2008) and Douglas-fir (El-Kassaby et al. 2011). Additionally, Rinn et al. (1996) found a strong fit $\left(R^{2}>0.8\right)$ between Resistograph ${ }^{\circledR}$ profiles and X-ray-based estimates of dry wood density for several different species. These results

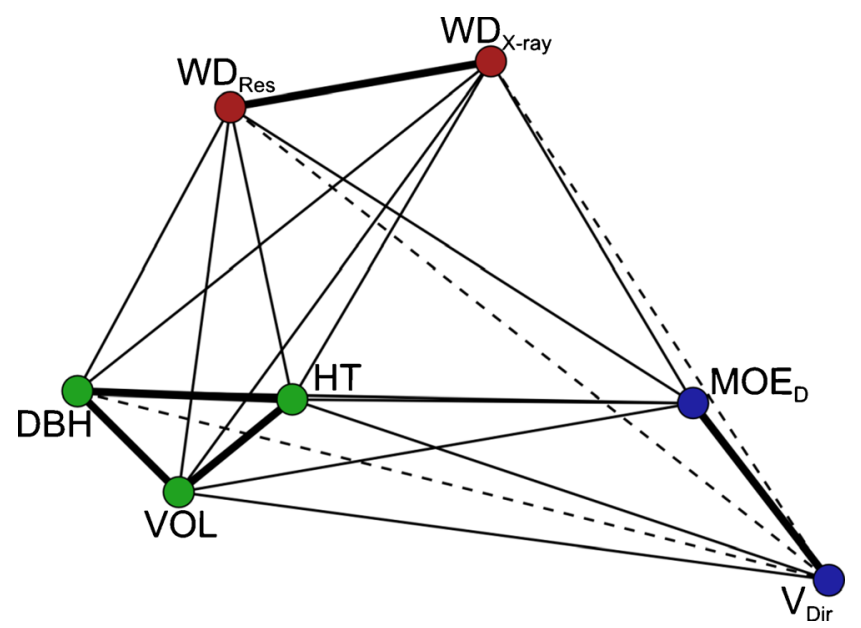

Fig. 2 Network analysis based on phenotypic correlations among measured traits (line thickness within trait clusters for emphasis; dashed lines represent negative correlations). Cluster I [green] (HT tree height, $V O L$ estimated volume, $D B H$ diameter at breast height); cluster II $[$ blue $]\left(V_{D i r}\right.$ acoustic velocity, $M O E_{D}$ dynamic modulus of elasticity); cluster III [red] $\left(W D_{\text {Res }}\right.$ resistograph wood density, $W D_{X-\text { ray }} \mathrm{X}$-ray wood density) 
suggest that the Resistograph ${ }^{\circledR}$ has considerable utility in tree breeding programs interested in wood quality traits.

The weak and non-significant $(p>0.05)$ correlations between $\mathrm{WD}_{\text {Res }}$ and $V_{\text {Dir }}\left(r_{\mathrm{P}}=-0.05 ; r_{G}=0.01\right)$ in this study is mirrored by that of El-Kassaby et al. (2011) who also reported a weak genetic correlation between these two traits in Douglas-fir and further proposed that these tools likely measure completely unrelated underlying traits. This seems plausible given the two contrasting underlying concepts on which they are based (acoustics vs. mechanical resistance) and the weak relationship exhibited by their correlations. As proposed by Eckard et al. (2010), the weak correlation between $W_{\text {Res }}$ and $V_{\text {Dir }}$ suggests that these two measures could possibly be used as covariates of a wood quality index. Further, the nonsignificant $(p>0.05)$ phenotypic and genetic correlations between $V_{\text {Dir }}$ and $\mathrm{WD}_{\text {X-ray }}$ implies that acoustic velocity has limited common genetic basis to $\mathrm{WD}_{\mathrm{Res}}$. El-Kassaby et al. (2011) found moderate genetic correlation between $\mathrm{WD}_{\mathrm{X} \text {-ray }}$ and $V_{\text {Dir }}$ in Douglas-fir $\left(r_{G}=0.35\right)$. A study by Lenz et al. (2013) presented weak genetic and phenotypic correlations between $\mathrm{WD}_{\mathrm{X} \text {-ray }}$ and $V_{\text {Dir }}$ in white spruce (Picea glauca (Moench) Voss) $\left(r_{P}=0.12 ; r_{G}=0.13\right)$, and found a strong genetic link between $V_{\text {Dir }}$ and MFA .

The strong correlations between $V_{\mathrm{Dir}}$ and $\mathrm{MOE}_{\mathrm{D}}\left(r_{P}=0.92\right.$; $\left.r_{G}=0.97\right)$ were expected since $\mathrm{MOE}_{\mathrm{D}}$ is a derived variable from $V_{\text {Dir }}$ Results validating the use of $\mathrm{MOE}_{\mathrm{D}}$ for wood quality are limited in the literature; however, results using static MOE are abundant. Kennedy et al. 2013 found weak genetic and phenotypic correlations $\left(r_{\mathrm{P}}=0.27 ; r_{G}=0.32\right)$ between $\mathrm{MOE}_{\mathrm{D}}$ and Pilodyn wood density for Sitka spruce (Picea sitchensis (Bong.) Carrière). Wang et al. (2000) reported a moderate relationship $\left(R^{2}=0.66\right)$ between standing tree $\mathrm{MOE}_{\mathrm{D}}$ and static MOE of small clear Sitka spruce and western hemlock (Tsuga heterophylla (Raf.) Sarg.). El-Kassaby et al. (2011) reported good agreement between $\mathrm{MOE}_{\mathrm{D}}$ of standing 30-year-old Douglas-fir and static MOE of $1 \mathrm{~m}$ segments $\left(R^{2}=0.69\right)$. Jacques et al. (2004) and Eckard et al. (2010) reported strong genetic correlations between acoustic velocity and static MOE in hybrid larch (Larix $\times$ eurolepis Henry) $\left(r_{G}=0.83\right)$ and loblolly pine $\left(r_{G}=0.67\right)$, respectively. Moderate and positive relationships between acoustic velocity and static MOE have been also been reported for Scots pine (Pinus sylvestris L.) $\left(R^{2}=0.53\right)$ (Auty and Achim 2008) and Douglas-fir $\left(R^{2}=0.62\right)$ (El-Kassaby et al. 2011).

Interestingly, there were no significant $(p<0.05)$ negative phenotypic or genetic wood quality-growth trait correlations in this study. Pâques et al. (2010) reported weak and nonsignificant phenotypic correlations between MOE and stem growth in hybrid larch wood (Larix $\times$ eurolepis Henry). Zobel and van Buijtenen (1989; Table 5) reported similar wood quality-growth trait relationships for Larix. The disparity between the strong and favorable correlations between HT and all measures of wood quality and weak correlations between DBH and wood traits is likely a result of the significant $G \times E$ variance in DBH. Zobel and Jett (1995; p. 216) noted that this difference is not uncommon, despite the strong correlation between DBH and HT. $V_{\text {Dir }}$ gave consistent positive and moderately strong genetic correlations for all three growth traits $\left(r_{G}=0.36-0.45\right)$. Phenotypic correlations for $V_{\text {Dir }}$ and growth traits were much lower, producing only one weak and significant value for with $\mathrm{HT}\left(r_{P}=0.16\right) . \mathrm{MOE}_{\mathrm{D}}$ mirrored $V_{\text {Dir }}$ and gave similar genetic and phenotypic correlations. Phenotypic correlations between $\mathrm{MOE}_{\mathrm{D}}$ and growth attributes (HT, VOL, and DBH) in this study were similar to those reported by Pâques et al. (2010).

The absence of negative wood quality-growth correlations (Figs. 1 and 2) is likely to be associated with the unique pithto-bark wood density profile in western larch. Jozsa and Sen (1992) reported that western larch displays a trend of increasing average annual ring density throughout the juvenile growth period ( $0-15$ years), after which ring density largely remains constant at the mature level. This distinguishing wood density profile is unlike that of other commercial softwood species in BC. However, the wood density profile of western larch is comparable with other fast growing conifers such as loblolly pine (Jordan et al. 2008) and radiata pine (Wilkes 1989). The correlation is not only advantageous to tree breeders, but also to forest managers whose reliance on second growth forests continues to increase. As suggested by Jaquish et al. (1995), the relatively short period of juvenile growth of western larch favorably complements the demands of forest managers by delivering trees with higher relative proportions of mature wood by time of harvest. Further, the desirable relationship suggests that there is sufficient potential (space) to generate genetic gain in future selection activities performed at the multi-trait level (e.g., an undesirable decrease of yield as a result of selection for wood density).

\section{Conclusions}

Of the in situ assessment methods tested the Resistograph ${ }^{\circledR}$ F300 provided the best surrogate estimate of western larch wood density. Resistance drilling measurements from the "F300" were strongly correlated at the genetic level with wood density as measured by X-ray densitometry. The acoustic method of wood stiffness measurement estimated by the Director ${ }^{\circledR}$ ST300 and the derived dynamic modulus of elasticity estimate did not match the reliability of the "F300" in predicting actual wood density.

The weak genetic correlations displayed by acoustic velocity and dynamic modulus of elasticity suggest limited dependability for their use as fast in situ wood density assessment methods in this species. Further, this study confirmed that resistance drilling is a reliable predictor of wood density in western larch. Additionally, the significant family 
variation for resistance drilling in combination with the unique wood density profile of western larch provides the prospect of improving wood quality using the "F300" within rapid in situ selection programs while maintaining strong growth attributes.

Acknowledgments We thank the Ministry of Forests, Lands and Natural Resource Operations for access to the progeny testing trials and providing valuable phenotypic data.

Funding This work is supported by the Natural Sciences and Engineering Research Council of Canada (NSERC), Discovery Grants to SDM and YAE and NSERC-IRC to YAE.

\section{References}

Andrews M (2002) Wood quality measurement-son et lumière. NZ J For 47:19-21

Auty D, Achim A (2008) The relationship between standing tree acoustic assessment and timber quality in Scots pine and the practical implications for assessing timber quality from naturally regenerated stands. Forestry 81:475-487. doi:10.1093/forestry/cpn015

Bastian M, Heymann S, Jacomy M (2009) Gephi: open source software for exploring and manipulating networks. International AAAI Conference Weblogs Social Media [http://www.aaai.org/ocs/index. $\mathrm{php} / \mathrm{ICWSM} / 09 /$ paper/view/154]

Blondel VD, Guillaume JL, Lambiotte R, Lefebvre E (2008) Fast unfolding of communities in large networks. J Stat Mech 2008: $\mathrm{P} 10008$

Bouffier L, Charlot C, Raffin A, Rozenberg P, Kremer A (2008) Can wood density be efficiently selected at early stage in maritime pine (Pinus pinaster Ait.)? Ann For Sci. doi: 10.1051/forest:2007078

Bucur V (2006) Acoustics of wood, 2nd edn. Springer, Berlin

Burton PJ (2010) Striving for sustainability and resilience in the face of unprecedented change: the case of the Mountain Pine Beetle outbreak in British Columbia. Sustainability 2:2403-2423

Carlson CE, Byler JW, Dewey JE (1995) Western larch: pest tolerant conifer of the Northern Rocky Mountains. In: Schmidt WC, McDonald KJ (eds) Ecology and management of Larix forests: A look ahead. U.S. Dep Agric For Serv, Intermtn Res Sta, Ogden, UT. Gen Tech Rep GTR-INT-319 pp 123-129

Cave ID, Walker JCF (1994) Stiffness of wood in fast grown plantation softwoods: the influence of microfibril angle. For Prod J 44:43-48

Chantre G, Rozenberg P (1997) Can drill resistance profiles (Resistograph) lead to within-profile and within-ring density parameters in Douglas fir wood? In: Zhang SY, Gosselin R, Chauret G (eds) Proc. CTIA-I UFRO In ter. Wood Quality Workshop: Timber management toward wood quality and end-product values. Forintek Canada, Sainte-Foy, pp 41-47

Cherry ML, Vikram V, Briggs D, Cress DW, Howe GT (2008) Genetic variation in direct and indirect measures of wood stiffness in coastal Douglas-fir. Can J For Res 38:2476-2486

Cornelius J (1994) Heritabilities and additive genetic coefficients of variation in forest trees. Can J For Res 24:372-379

Eckard JT, Isik F, Bullock B, Li B, Gumpertz M (2010) Selection efficiency for solid wood traits in Pinus taeda using time-of-flight acoustic and micro-drill resistance methods. For Sci 56:233-241

El-Kassaby YA, Jaquish B (1996) Population density and mating pattern in Western Larch. J Hered 87:438-443

El-Kassaby Y, Mansfield S, Isik F, Stoehr M (2011) In situ wood quality assessment in Douglas-fir. Tree Genet Genomes 7:553-561
Evans R, Stringer S, Kibblewhite RP (2000) Variation of microfibril angle, density and fibre orientation in twenty-nine Eucalyptus nitens trees. Appita J 53:450-457

Falconer DS, MacKay TFC (1996) Introduction to quantitative genetics, 4th edn. Longman Scientific \& Technical, Burnt Mill, Harlow

Farmer JRRE, O'Reilly G, Shaotang D (1993) Genetic variation in juvenile growth of Tamarack (Larix laricina) in northwestern Ontario. Can J Res 23:1852-1862

Fins L, Rust M (1989) Heritability and genetic gain in western larch. In: Fins L (ed) Inland empire tree improvement cooperative, 13th progress report. University of Idaho Forest, Wildlife and Range Experiment Station, Moscow, Idaho, pp 46-51

Fujimoto T, Akutsu H, Nei M, Kita K, Kuromaru M, Oda K (2006) Genetic variation in wood stiffness and strength properties of hybrid larch (Larix gmelinii var. japonica $\times$ L. kaempferi). J For Res 32: 343-349

Gantz CH (2002) Evaluating the efficiency of the Resistograph to estimate genetic parameters for wood density in two softwood and two hardwood species. Dissertation, College of Natural Resources, North Carolina State University

Gao S, Wang X, Wang L, Allison RB (2013) Effect of temperature on acoustic evaluation of standing trees and logs: part 2-field investigation. Wood Fiber Sci 45:15-25

Gerhards CC (1982) Longitudinal stress waves for lumber stress grading: factors affecting applications: state of the art. For Prod J 32: $20-25$

Gilmour AR, Cullis BR, Welham SI, Thompson R (2002) ASReml reference manual. NSW Agriculture Biometrical Bulletin 3

Gray JD, Grushecky ST, Armstrong JP (2008) Stress wave velocity and dynamic modulus of elasticity of yellow-poplar ranging from $100 \%$ to $10 \%$ moisture content. In: Jacobs, DF, Michler CH (eds) Proceedings, 16th central hardwood forest conference Newtown Square, PA: U.S. Department of Agriculture, Forest Service, Northern Research Station. Gen Tech Rep NRS-P-24 pp 139-142

Gwaze D, Stevenson A (2008) Genetic variation of wood density and its relationship with drill resistance in shortleaf pine. South J Appl For $32: 130-133$

Isik F, Li B (2003) Rapid assessment of wood density of live trees using Resistograph for selection in tree improvement programs. Can J For Res 33:2426-2435

Jacques D, Marchal M, Curnel Y (2004) Relative efficiency of alternative methods to evaluate wood stiffness in the frame of hybrid larch (Larix $\times$ eurolepis Henry) clonal selection. Ann For Sci 61: $35-43$

Jaquish B, Howe G, Fins L, and Rust M (1995) Western larch tree improvement programs in the inland empire and British Columbia. In: Schmidt WC, McDonald KJ (eds) Ecology and management of Larix forests: A look ahead. U.S. Dep Agric For Serv, Intermtn Res Sta, Ogden, UT. Gen Tech Rep GTR-INT-319 pp 452-460

Jordan L, Clark A III, Schimleck LR, Hall DB, Daniels RF (2008) Regional variation in wood specific gravity of planted loblolly pine in the United States. Can J For Res 38:698-710

Jozsa LA, Sen P (1992) Yellow-cypress wood quality. Report prepared for the B.C. Ministry of Forests, Project No. 1212K022: Forintek Canada Corp., Vancouver. BC. 31pp

Kellogg RM (1982) Coming to grips with wood quality. For Chron 58: 254-257

Kennedy SG, Cameron AD, Lee SJ (2013) Genetic relationships between wood quality traits and diameter growth of juvenile core wood in Sitka spruce. Can J Res 43:1-6

Leech SM, Almuedo PL, O'Neill G (2011) Assisted migration: adapting forest management to a changing climate. BC J Ecosyst Manag 12: $18-34$

Lenz P, Auty D, Achim A, Beaulieu J, Mackay J (2013) Genetic improvement of white spruce mechanical wood traits - early screening by means of acoustic velocity. Forests 4:575-594 
Lin CJ, Wang SY, Lin FC, Chiu CM (2003) Effect of moisture content on the drill resistance value in Taiwania plantation wood. Wood Fiber Sci 35:234-238

Lindström H, Harris P, Sorensson CT, Evans R (2004) Stiffness and wood variation of 3-year old Pinus radiata clones. Wood Sci Technol 38: 579-597

Lynch M, Walsh B (1998) Genetics and analysis of quantitative traits. Sinauer, Sunderland, Mass

Miles PD, Smith WB (2009) Specific gravity and other properties of wood and bark for 156 tree species found in North America. U.S. Dep Agric For Serv Res Note NRS-38, Newtown Square, PA

Millman M (1976) Metric volume and V-bar tables derived from BCFC whole stem cubic metre volume equations. Vancouver, BC

Mullins EJ, McKnight TS (1981) Canadian woods: their properties and uses, 3rd edn. University of Toronto Press, Toronto

Namkoong G (1966) Inbreeding effects on estimation of genetic additive variance. Forest Sci 12:8-13

Pâques LE, Millier F, Rozenberg P (2010) Selection perspectives for genetic improvement of wood stiffness in hybrid larch (Larix $\times$ eurolepis Henry). Tree Genet Genomes 6:83-92

Park YS, Fowler DP (1987) Genetic variances among clonally propagated populations of tamarack and the implications for clonal forestry. Can J For Res 17:1175-1180

Pellerin R, Ross RJ (2002) Nondestructive evaluation of wood. Forest Products Society, Madison, Wisconsin

Perron M, DeBlois J, Desponts M (2013) Use of resampling to assess optimal subgroup composition for estimating genetic parameters from progeny trials. Tree Genet Genomes 9:129-143

Rehfeldt GE (1992) Breeding strategies for Larix occidentalis: adaptations to the biotic and abiotic environment in relation to improving growth. Can J For Res 22:5-13

Rehfeldt GE, Jaquish BC (2010) Ecological impacts and management strategies for western larch in the face of climate change. Mitig Adapt Strateg Glob Chang 15:283-306

Rinn F, Scheweingruber FH, Schar E (1996) Resistograph and X-ray density charts of wood comparative evaluation of drill resistance profiles and X-ray density charts of different wood species. Holzforschung 50:303-311
Sandoz JL (1993) Moisture content and temperature effect on ultrasound timber grading. Wood Sci Technol 27:373-380

Schmidt WC and Shearer RC (1995) Larix occidentalis: a pioneer of the North American West. In: Schmidt WC, McDonald KJ (eds.) Ecology and management of Larix forests: A look ahead U.S. Dep Agric For Serv, Intermtn Res Sta, Ogden, UT. Gen Tech Rep GTRINT-319pp 33-37

Schmidt WC, Shearer EC, Roe AL (1976) Ecology and silviculture of western larch forests. U.S. Dep Agric Tech Bull 1520

Stonecypher RW, Piesch RF, Helland GG, Chapman JG, Reno HJ (1996) Results from test of selected parents of Douglas-fir (Pseudotsuga menziesii [Mirb.] Franco) in an applied tree improvement program. Sci Monogr 32:35

Summitt R, Sliker A (1980) CRC Handbook of materials science, IV: wood. CRC, Boca Raton

Ukrainetz NK, O’Neill GA (2010) An analysis of sensitivities contributing measurement error to Resistograph values. Can J For Res 40: 806-811

Ukrainetz NK, Kang K-Y, Aitken SN, Stoehr M, Mansfield SD (2008) Heritability, phenotypic and genetic correlations of coastal Douglasfir (Pseudotsuga menziesii) wood quality traits. Can J For Res 38: 1536-1546

Wang X, Ross RJ, McClellan M, Barbour RJ, Erickson JR, Forsman JW, McGinnis GD (2000) Strength and stiffness assessment of standing trees using a nondestructive stress wave technique. Res Pap FPLRP-585. U.S. Dep Agric For Serv, For Prod Lab, Madison, WI, p 11

White TL, Adams WT, Neale DB (2007) Forest genetics. CABI, Oxford

Wiemann MC (2010) Chapter 02: Characteristic and Availability of Commercially Important Woods. In: Ross RJ (ed) Wood Handbook. Gen Tech Rep FPL-GTR-190. US Dep Agric For Serv, For Prod Lab, Madison, WI, pp 2.1-2.45

Wilkes J (1989) Variation in wood density of Pinus radiata in New South Wales, Australia. Can J Res 19:289-294

Woods J (2011) Forest genetics council of bc business plan 2010-2011. Forest Genetics Council of BC, Victoria

Zobel BJ, Jett JB (1995) Genetics of wood production. Springer, Berlin

Zobel BJ, van Buijtenen JP (1989) Wood variation. Its causes and control. Springer, Heidelberg 